or the air quality at work places, no generally agreed limits or guideline values are yet available. For certain types of building material (e.g., particle boards, carpets, paints) producers have agreed on a voluntary basis on standards to limit the emissions of their products.
Currently, a working group of the European Commission is working to elaborate criteria for the assessment of emission data from building materials making use of results from ongoing activities in several member states.

\title{
One-dimensional water transport in covercrete - application of non-destructive methods
}

\section{J. KAUFMANN, W. STUDER \\ EMPA Department Concrete/Binding Agents}

\section{INTRODUCTION}

The durability of concrete, especially the corrosion of reinforcing steel due to carbonation or the presence of chlorides or other depassivating substances, is a growing problem and has led to a great deal of investigation during the last few years. Gas permeability, gas exchange and the transport of halogenides depend strongly on the humidity distribution or humidity changes, especially in the outer layers of concrete (covercrete) where weather conditions have a large influence. Therefore the investigation of humidity distribution during suction and evaporation tests on samples with one moulded surface are appropriate. Measurement of mass changes is a simple method for detecting the total amount of water exchanged, but without further assumptions no conclusions about the moisture distribution within concrete can be derived. Often other methods like $\gamma$-ray absorption [1], conductivity measurements or microwave absorption are applied to this problem $[2,3]$, but insufficient spatial and signal resolutions, as well as secondary parameters such as solubility of ions lead to unsatisfactory results, especially if concrete containing aggregates of $32 \mathrm{~mm}$ is being studied. Therefore non-destructive tomographic methods like magnetic resonance imaging (MRI) and $\mathrm{x}$-ray tomography are used to detect humidity distributions within concrete samples during suction tests.

\section{MASS MEASUREMENTS}

\subsection{Sample preparation}

The samples for the suction and water loss test were taken from 4 different walls [4] approximately 4 or 5 years after their production, so they can be considered as fully hydrated. The mix design is shown in Table 1. Through variation of water and cement content the cementstone volume, viz. the quantity and grain size distribution of aggregates with maximum grain size $32 \mathrm{~mm}$, was kept constant. In a central region (avoiding boundary zones and vibration points) 60 cores ( $d=50 \mathrm{~mm}, l=200 \mathrm{~mm}=$ wall thickness) were taken. These were cut into lengths of $25 \mathrm{~mm}, 50 \mathrm{~mm}$ and
Table 1 Mix design

\begin{tabular}{lrrrr}
\hline & Mix 1 & Mix 2 & Mix 3 & Mix 4 \\
\hline Sand 0/4 mm & 627 & 622 & 633 & $627 \mathrm{~kg} \mathrm{~m}^{-3}$ \\
Gravel 4/32 mm & 1332 & 1322 & 1332 & $1332 \mathrm{~kg} \mathrm{~m}^{-3}$ \\
Cement OPC & 294 & 258 & 230 & $230 \mathrm{~kg} \mathrm{~m}^{-3}$ \\
Water & 147 & 129 & 158 & $138 \mathrm{~kg} \mathrm{~m}^{-3}$ \\
Ratio w/c & 0.5 & 0.5 & 0.6 & 0.6 \\
Air pore content & 2.6 & 5 & 2.1 & $5.2 \mathrm{vol}^{\circ}$ \\
Bulk density & 2401 & 2331 & 2399 & $2328 \mathrm{~kg} \mathrm{~m}^{-3}$ \\
\hline
\end{tabular}

$100 \mathrm{~mm}$. All samples had one moulded surface at one end. Each series was composed of five samples which were equal with respect to position and distance to the vibration points.

After a short intermediate storage in a laboratory room, the samples were stored at $20^{\circ} \mathrm{C}$ and $35 \%, 70 \%$ and $90 \% \mathrm{RH}$ until the beginning of the suction test (half of the samples stored at $35 \% \mathrm{RH}$ were dried for 4 days at $50^{\circ} \mathrm{C}$ ). The storage time was $300-400$ days, so that a uniform humidity distribution could be expected within the samples.

\subsection{Suction test}

\subsubsection{Description of test procedure}

For the suction test all samples had previously been sealed with an aluminium adhesive tape on all surfaces except the moulded surface. The tape could be applied without humidity changes. The influence of the sealing of the cut surface on water uptake was low; the water uptake through the other surfaces without sealing was considerable. Sealing with this tape guarantees one-dimensional water uptake with sufficient accuracy. Then the samples were put into closed boxes with the non-sealed surface $3 \mathrm{~mm}$ deep in water $\left(20^{\circ} \mathrm{C}\right)$. Periodically the samples were weighed. The first measurement was carried out after $15 \mathrm{~min}$. After the last measurement, 14 days later, the aluminium tape was removed and the samples were stored under water for another 3 days and then weighed again. 


\subsubsection{Results}

Mass uptake versus time (log-log plot) is given in Fig. 1 for different sample lengths of specimens with the same pre-storage conditions and the same concrete type. The average of five samples is plotted. The shorter cores $(25 \mathrm{~mm}$ and $50 \mathrm{~mm}$ ) show geometrically caused saturation behaviour which, as expected, occurs earlier or later depending on concrete composition. Until saturation (first $24 \mathrm{~h}$ ) sample length had no significant influence on the water uptake. Deviations are caused only by sample inhomogeneity (aggregate distribution).

Assuming an upward-moving water front, a penetration height can be derived by rescaling the mass uptake data after a certain time with the maximum possible value (after the suction test and additional storage of the unsealed samples below water). For the storage humidities considered $(35 \% / 70 \% / 90 \% \mathrm{RH})$ and the heat treatment for one week at $50^{\circ} \mathrm{C}$, no large influence was found for these calculated penetration heights. A typical example is given in Fig. 2.

As already mentioned, water uptake took place through the moulded surface. Thus the observed higher values during the first phase (up to $1 \mathrm{~h}$ ) in comparison with the following linear (log-log) development can be explained as an influence of the higher porosities in the

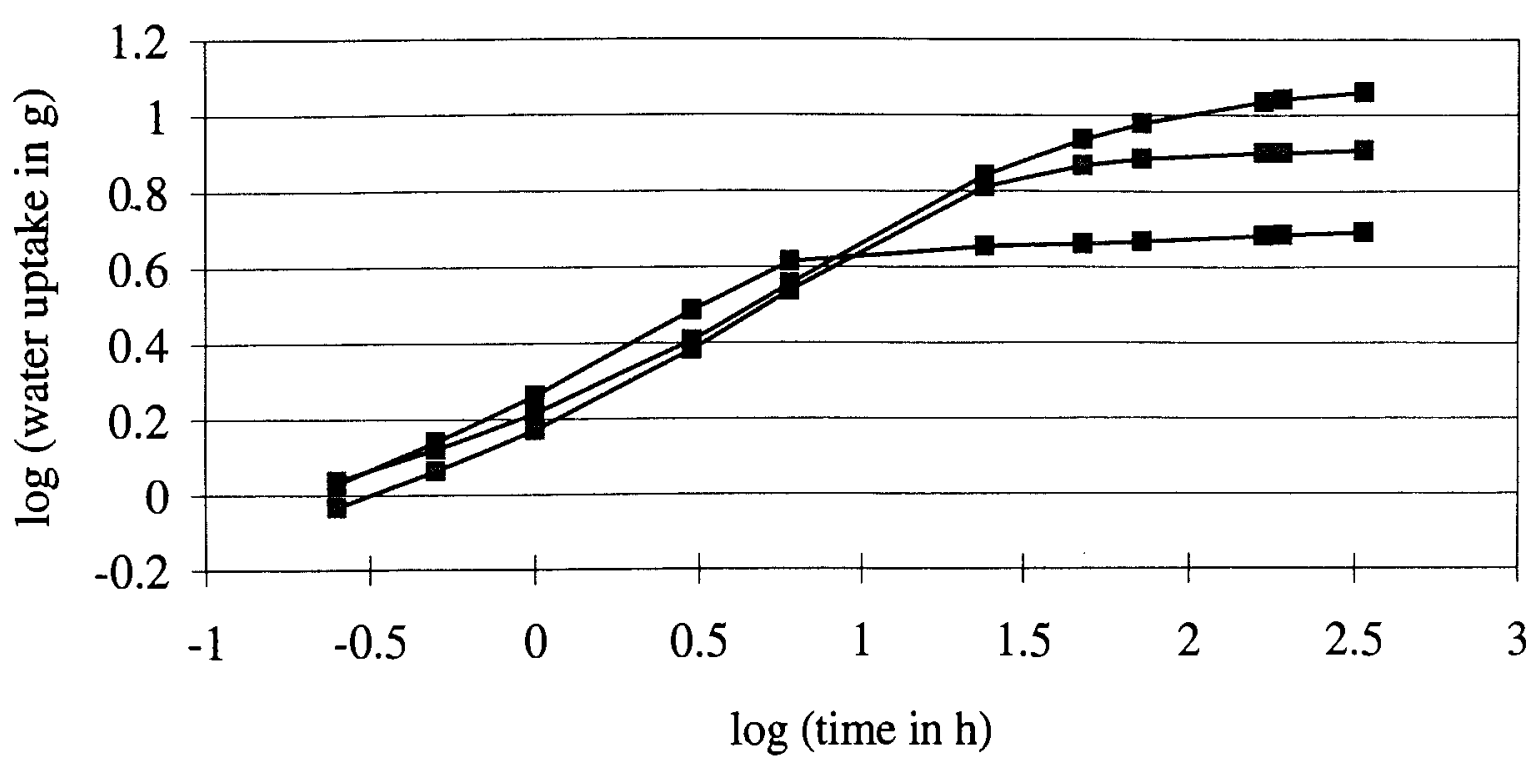

\section{length $25 \mathrm{~mm} \rightarrow-$ length $50 \mathrm{~mm} \rightarrow-$ length $100 \mathrm{~mm}$}

Fig. 1 Influence of sample length on water uptake (in g) of mix 3 (prestored at $35 \% \mathrm{RH}$ ).

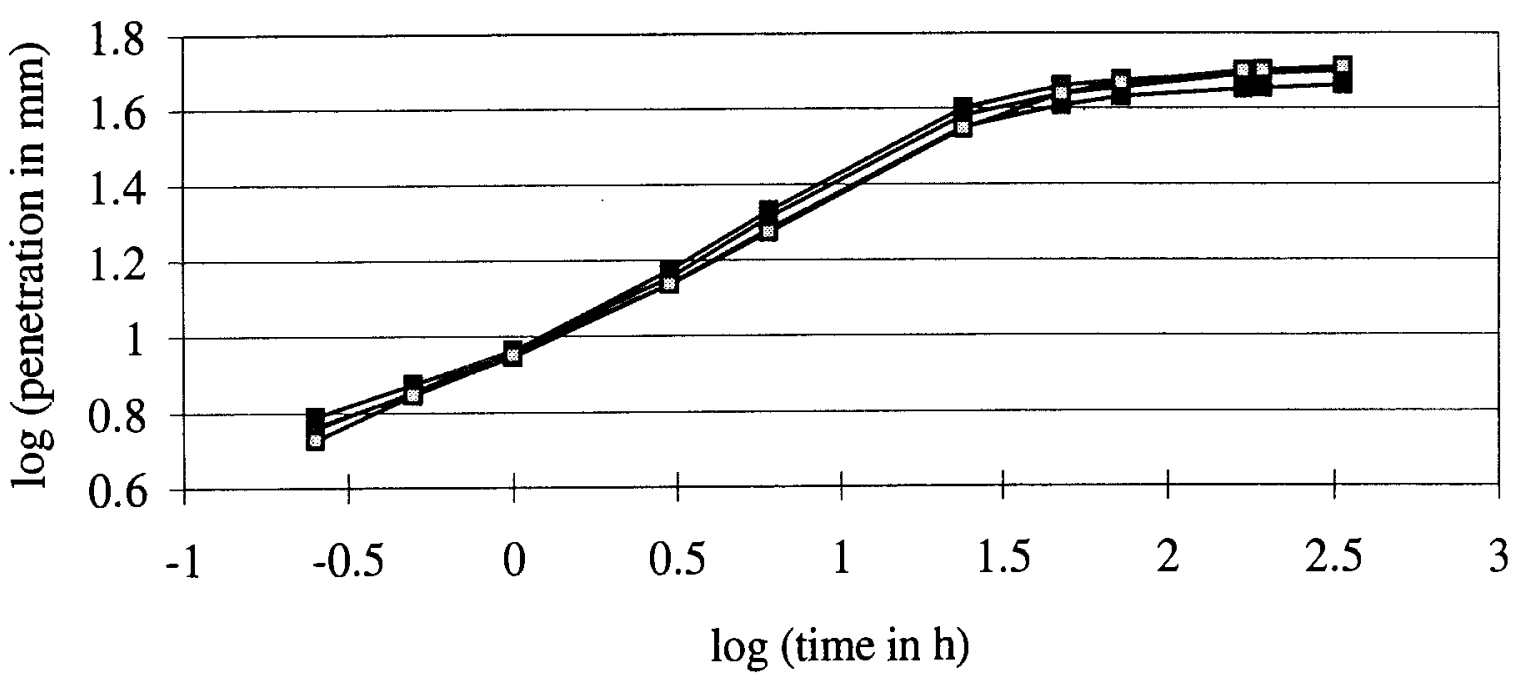

$\rightarrow-$ heat treatment $1 \mathrm{w} 50^{\circ} \mathrm{C} \rightarrow-$ Prestorage humidity $35 \%$ R.H.
$\rightarrow$ Prestorage humidity $70 \%$ R.H. $\rightarrow$ - Prestorage humidity $90 \%$ R.H.

Fig. 2 Calculated penetration heights of mix 3 (sample length $50 \mathrm{~mm}$ ) as a function of prestorage condition. 


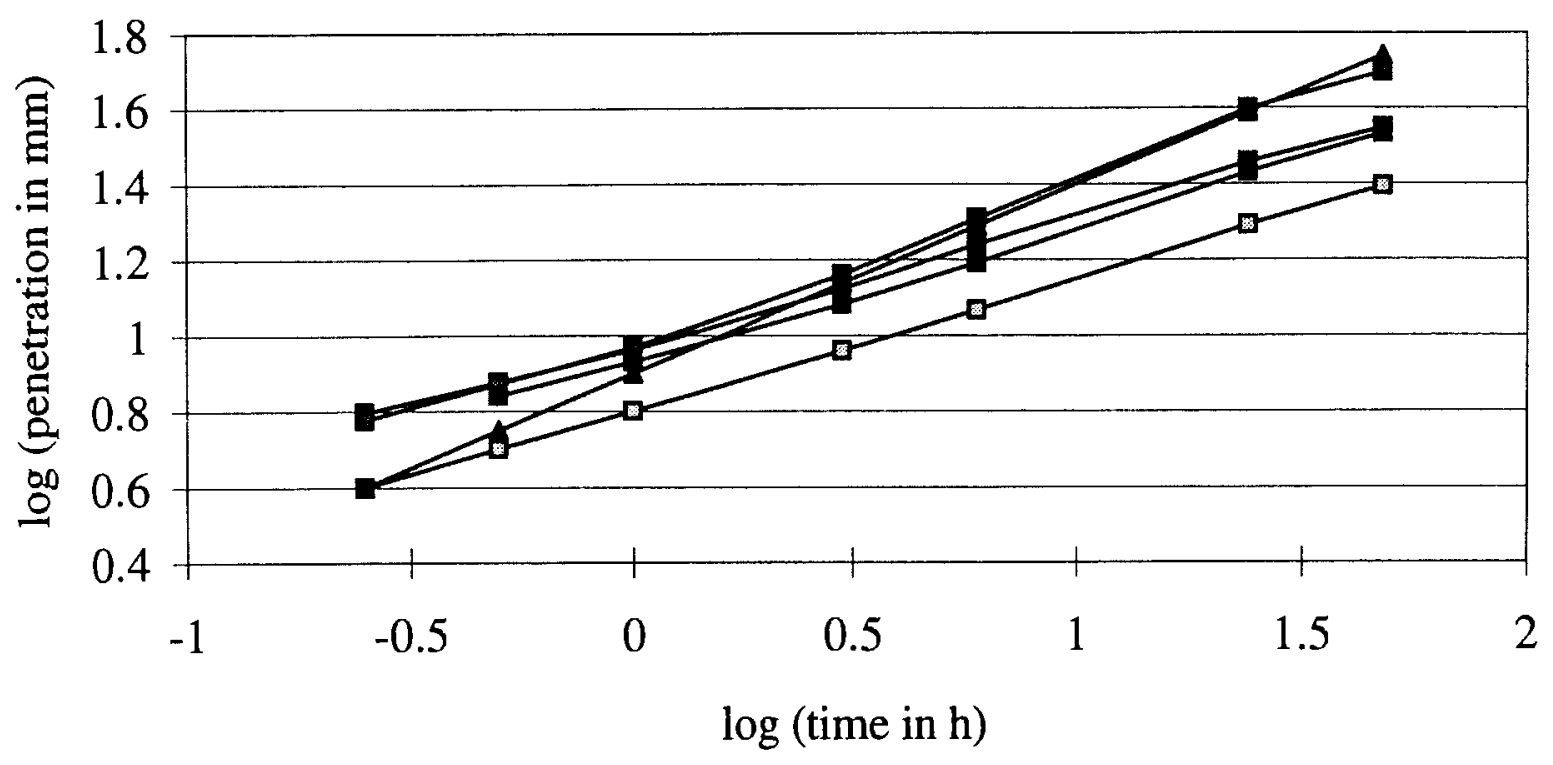

\section{$\rightarrow-\operatorname{Mix} 4 \rightarrow-\operatorname{Mix} 3 \rightarrow-\operatorname{Mix} 1 \rightarrow-\operatorname{Mix} 2 \rightarrow$ root of time}

Fig. 3 Comparison of penetration heights in suction test (mean values) with theory (root of time).

outer layer. This effect was not found in suction tests with cut surfaces. As the penetration heights did not depend significantly on sample length and prestorage conditions, the average of samples with the same length and prestorage condition (for times not affected by saturation) could be employed to obtain more accurate results. The results derived are shown in Fig. 3, where the penetration heights of the four different walls are plotted against time $(\log -\log )$. Significant deviation from the expected 'root of time' behaviour are obvious. Apart from the beginning phase (influence of moulded surface) the time dependence of water suction can be described by a power law in the form

$$
W S=c t^{x}
$$

The factor $c$ showed considerable scatter for individual samples whereas the exponent $x$ was unexpectedly constant and showed little dependence on prestorage conditions. The expected 'root of time' dependence $(x=0.5)$ was found only for concrete with $w / c 0.6$ and airpore content 2 vol \% (mix 3), and all samples predried at $105^{\circ} \mathrm{C}$ taken from the other walls with different concrete types. All other samples of the other three walls (including pre-drying at $50^{\circ} \mathrm{C}$ ) showed lower time constants ranging from 0.35 to 0.4 . This deviation from root of time behaviour was mentioned by other authors but had been attributed to inhomogeneous humidity distribution within samples, which can be neglected here $[5,6]$. Further results are given in reference $[7]$.

\subsection{Evaporation test}

\subsubsection{Description of test procedure}

After the suction test the same samples were stored in water and then the 'completely' saturated (except air pores) cores were sealed again with aluminium tape. Various tests showed the high quality of this sealing method. The moulded surface was kept unsealed. Then samples were placed $3 \mathrm{~mm}$ deep in water (see suction test) with the moulded surface down, for intermediate storage. Afterwards the samples were brought into climatic chambers $\left(35 \%\right.$ or $\left.70 \% \mathrm{RH} / 20^{\circ} \mathrm{C}\right)$ where they were promptly 'dried off' with a damp cloth and then set aside with the moulded surface (non-sealed) standing free. Mass changes were then measured at various intervals. The first measurements took place after $15 \mathrm{~min}$, and the last after 3 weeks.

\subsubsection{Results}

In the evaporation test, no influence of sample length could be detected. The earlier prestorage condition also had no influence. Only the samples dried at $105^{\circ} \mathrm{C}$ (before the suction test) showed significantly higher evaporation rates. Therefore the average of sample length and prestorage conditions $(35 \% \mathrm{RH}, 70 \% \mathrm{RH}, 90 \% \mathrm{RH}$ and 1 week at $50^{\circ} \mathrm{C}$ ) could be derived to obtain lower standard deviations. The results for one wall are given in Fig. 4. The evaporation area was $19.6 \mathrm{~cm}^{2}$. The water loss through the moulded surface showed a typical, well reproducible time dependence. After an initial phase during which the water loss was almost proportional to time $\left(t^{0.77-0.89}\right)$ a sharp change followed, leading to strongly reduced water loss behaviour proportional to $t^{0.22-0.26}$.

The second phase lasted until the end of the test ( 3 weeks). The evaporation rate was found to be nearly independent of the surrounding humidity. In other evaporation tests with cut surfaces the initial phase could barely be detected and the dependence on evaporation humidities was greater. The evaporation rate in the initial 


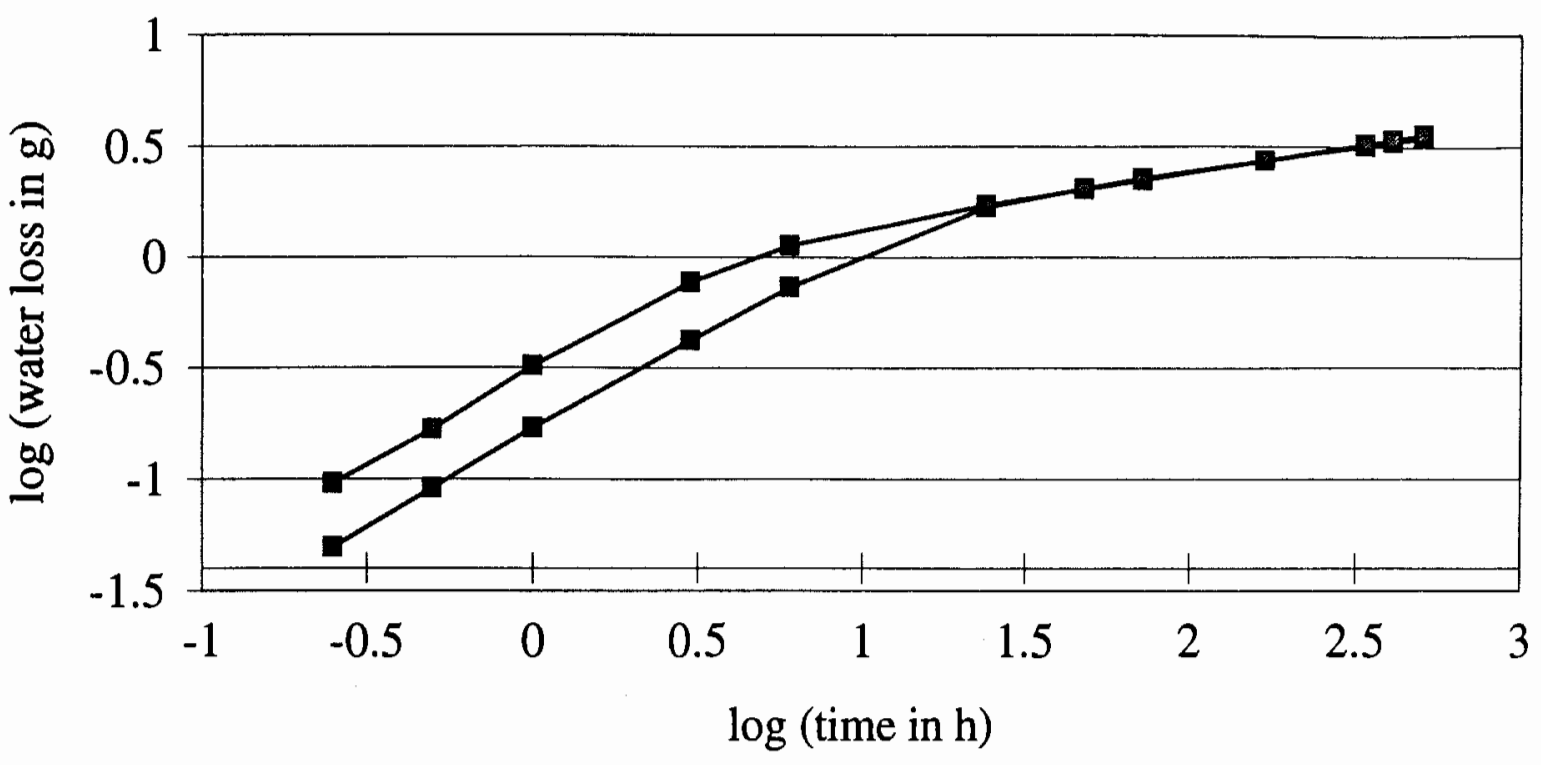

water loss at $70 \%$ R.H $\rightarrow-$ water loss at $35 \%$ R.H.

Fig. 4 Water loss (in g) through moulded surface of mix 3 (mean values).

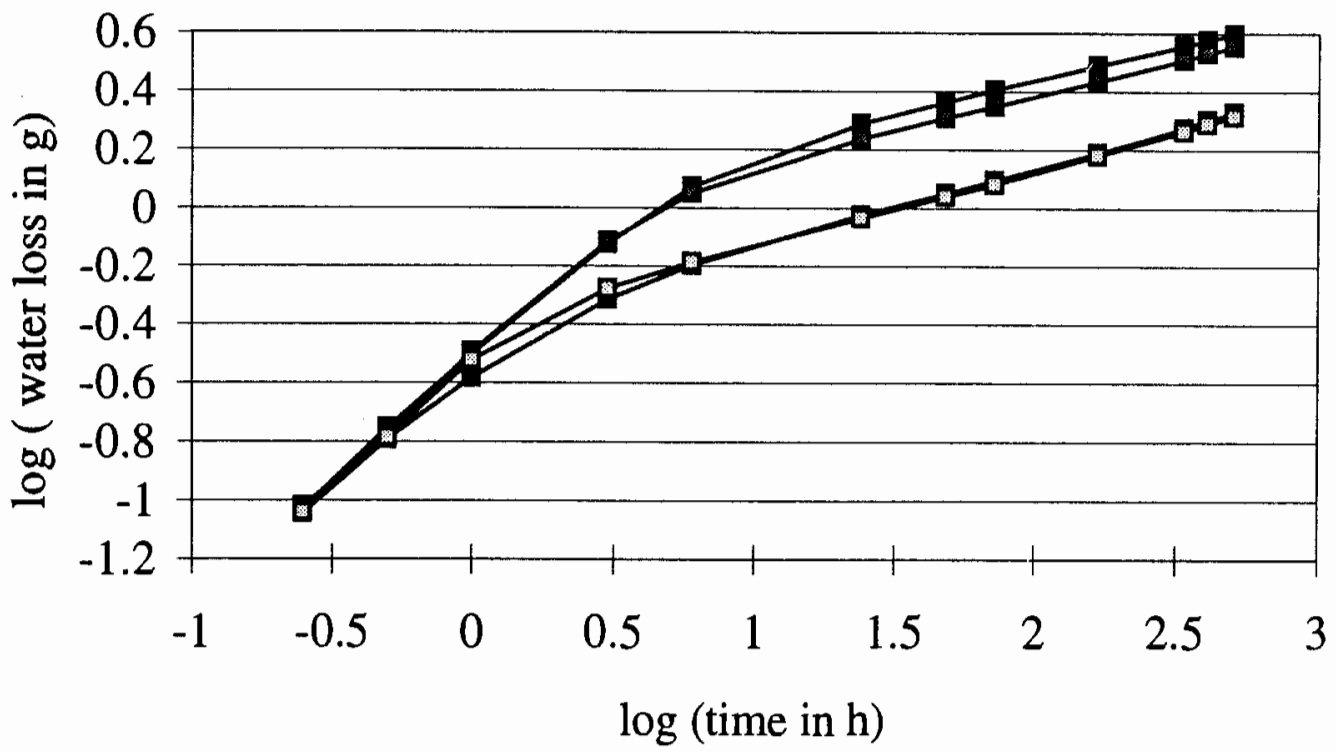

\section{$\operatorname{Mix} 4 \rightarrow-\operatorname{Mix} 3 \rightarrow-\operatorname{Mix} 1 \rightarrow-\operatorname{Mix} 2$}

Fig. 5 Water loss (in g) at $35 \% \mathrm{RH}$, surrounding humidity (mean values).

phase (moulded surfaces) corresponds to $60-90 \%$ of the quantity of water evaporating from free surfaces. Therefore it can be assumed that during the first phase larger pores directly connected with the surface are emptied. As the transition to the second phase is rather sharp, a completely different process must be responsible for the evaporation in this second phase.

The values for different concrete types are given in Fig. 5. The time at which the sharp transition occurs depends greatly on the $w / c$ ratio. The influence of airpore content (AP) is small. This influence was greater in evaporation tests with cut surfaces.

\section{TOMOGRAPHIC INVESTIGATIONS}

Tomographic methods with their good spatial resolution, as opposed to integral mass measurement, are best suited to observing the spatial water distribution directly during the suction test. Because of the low sample porosity (total porosity $\approx 14 \%$ ) and the resulting low quantity of water to be detected, instrumental limits are met. Nevertheless, it was possible to detect water fronts by using deuterium-MRI. 


\section{1 x-Ray computer tomography}

Applying $x$-ray computer tomography (carried out at EMPA), varying densities and atomic numbers in any given plane can be portrayed. As Fig. 6 shows (left, $450 \mathrm{kV}$; right, $100 \mathrm{kV}$ ) good resolution of the structure of the concrete is obtained. Aggregate, cementstone and voids are (non-destructively) visible. The picture taken with lower $\mathrm{x}$-ray energies even allows different aggregate types to be distinguished. Applying this method to water detection only with predried samples $\left(1 \mathrm{w}\right.$ at $\left.105^{\circ} \mathrm{C}\right)$ and regarding difference images before and after suction, the water uptake between aggregate stones can be observed.

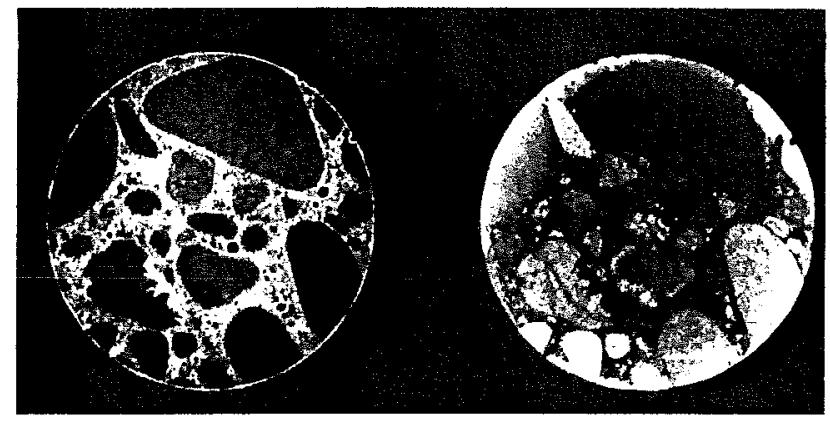

Fig. $6 \mathrm{x}$-Ray CT picture of concrete (left, $450 \mathrm{kV}$; right, $100 \mathrm{kV}$ ). Core diameter is $50 \mathrm{~mm}$.

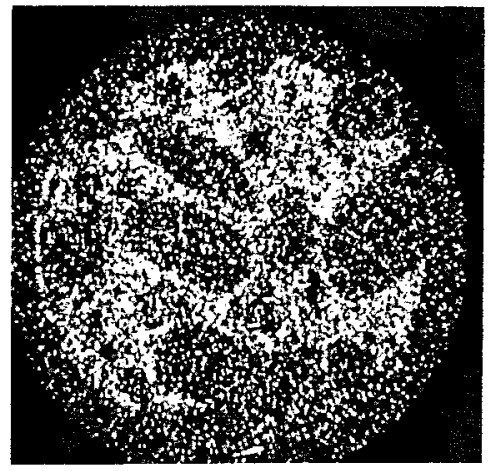

Fig. 7 Difference picture (after $5 \mathrm{~h}$ water suction). Core diameter is $50 \mathrm{~mm}$.

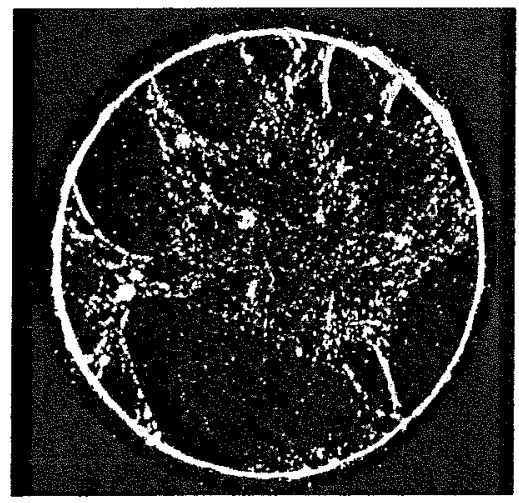

Fig. 8 Difference picture (after vacuum saturation). Core diameter is $50 \mathrm{~mm}$.
Airpores could not be filled by simple water storage (see Fig. 7).

After evacuating the samples and then flooding with water, the difference pictures (Fig. 8) showed small brighter spots (higher density) at the location of (larger) airpores. Thus they can be filled with water by vacuum saturation. The brighter signal around the samples is due to an aluminium tape that was applied after vacuum saturation to prevent evaporation. Apart from these results, $x$-ray tomography seems to be generally well applicable to structural concrete research and fracture investigations.

\subsection{Magnetic resonance imaging}

Another sophisticated method is magnetic resonance imaging (MRI) [8]. After the alignment of core spins in a magnetic field, high frequency fields applied additionally are resonance absorbed. In this way the distributions of certain elements can be detected ion-selectively and 3-dimensionally.

\subsubsection{Proton MRI}

Initially the signal of free protons ${ }^{1} \mathrm{H}$ is measured. Due to changes in relaxation times physically or chemically stronger-bound water can be distinguished well from 'Iree' water. Bound water was not detected in our case. Also, even after a drying treatment at $105^{\circ} \mathrm{C}$ (4 days) the remaining water signal was too intense to observe changes in water distribution during the suction test. Fig. 9 shows spatially well-resolved distributions of rest water (after $105^{\circ} \mathrm{C}, 4$ days). Convex forms of brighter spots (water) and direct observation by cutting the sample indicate that these regions sometimes correspond to aggregate grains, although the aggregate used in the tests consisted of Swiss alluvial gravel with (normally) low porosities.

\subsubsection{Deuterium MRI}

To avoid problems with rest water and to be able to observe the transport path of penetrating water, measurements were performed with deuterated water and deuterium MRI [9]. The resonance frequencies of water

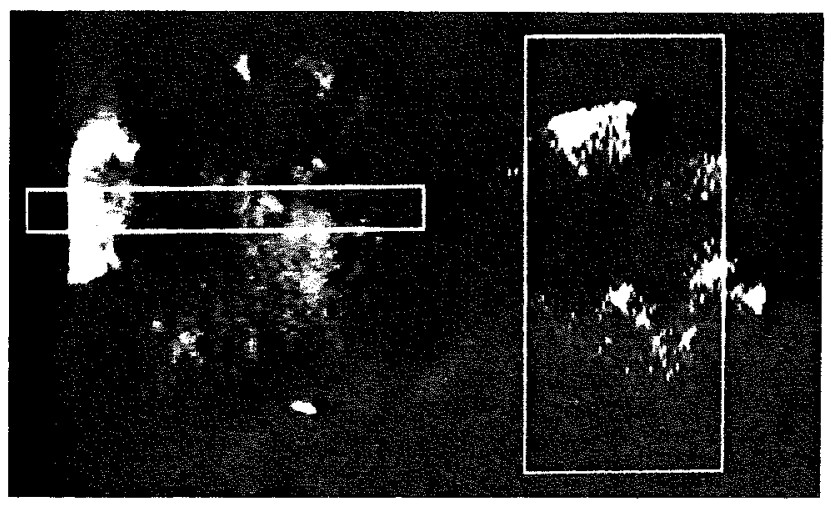

Fig. 9 Water distribution of sample predried at $105^{\circ} \mathrm{C}$ with core diameter $50 \mathrm{~mm}$. 


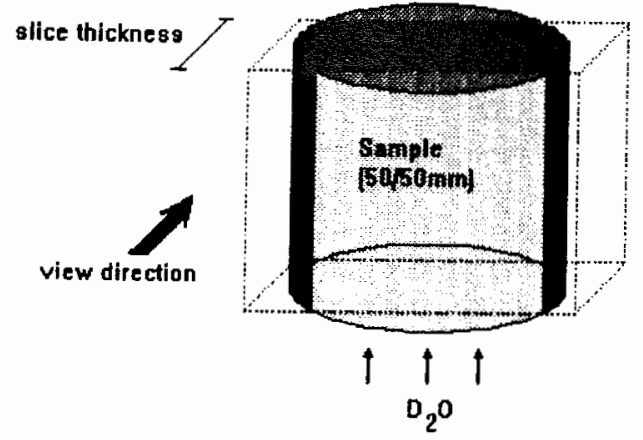

Fig. 10 Parameter arrangement for MRI measurement.

and deuterated $(99 \%)$ water are quite different so that $\mathrm{D}_{2} \mathrm{O}$ can be used as a tracer. In the suction tests with deuterated water no significant difference was found compared with normal water. Samples prestored at $35 \%$ $\mathrm{RH}$ or $90 \% \mathrm{RH}$ were sealed with an epoxy layer (metals such as aluminium tapes could not be used because of technical reasons), leaving the moulded surface untreated. They were then put $3 \mathrm{~mm}$ deep into water. After time intervals of $3 \mathrm{~h}, 6 \mathrm{~h}, 24 \mathrm{~h}$ and $48 \mathrm{~h}$ their mass was measured and they were tested by MRI. These MRI measurements lasted about $12 \mathrm{~min}$. The observation geometry is given in Fig. 10. Due to low intensities, the signal intensities within a slice of thickness $25 \mathrm{~mm}$ were added together. Spatial resolution was therefore $1 \times 1 \times 25 \mathrm{~mm}^{3}$. The intensity distributions of upward moving water showed good resolution.

Intensity profiles showed a sharply defined horizontal water front. Thus, along a line below the front height (penetration height) the intensity was nearly constant, aside from effects resulting from the moulded surface and aggregate grains. It fell to zero above this penetration

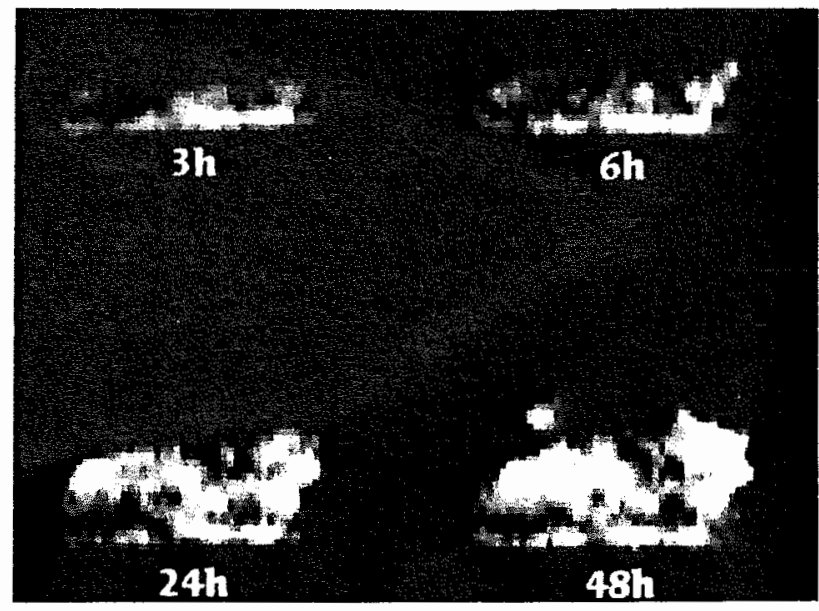

Fig. 11 Suction experiment (mix 3 ; prestorage at $35 \% \mathrm{RH}$ ). $(\longmapsto-1 \approx 10 \mathrm{~mm})$

height. As an example, Fig. 11 shows (non-destructive MRI) such upward moving fronts during the suction test. For different samples the penetration heights (MRI) were obtained from the associated curves. In Figs 12 and 13 two examples are given for two different concrete types which were prestored at $35 \% \mathrm{RH}$. The calculated penetration height (derived from the suction test) is compared with the penetration height by MRI. While the calculated penetration heights are mean values of 5 samples. The curves are fairly parallel, i.e. the time constants are similar, whereas lower values were found for the penetration heights by MRI. Even concrete samples prestored at $90 \% \mathrm{RH}$ could be investigated with deuterium MRI. Derived penetration heights are given in Figs 14 and 15. The curves still remain more or less parallel, for the heights by MRI the values are much lower than those calculated. At this higher prestorage humidity the penetration heights were significantly lower
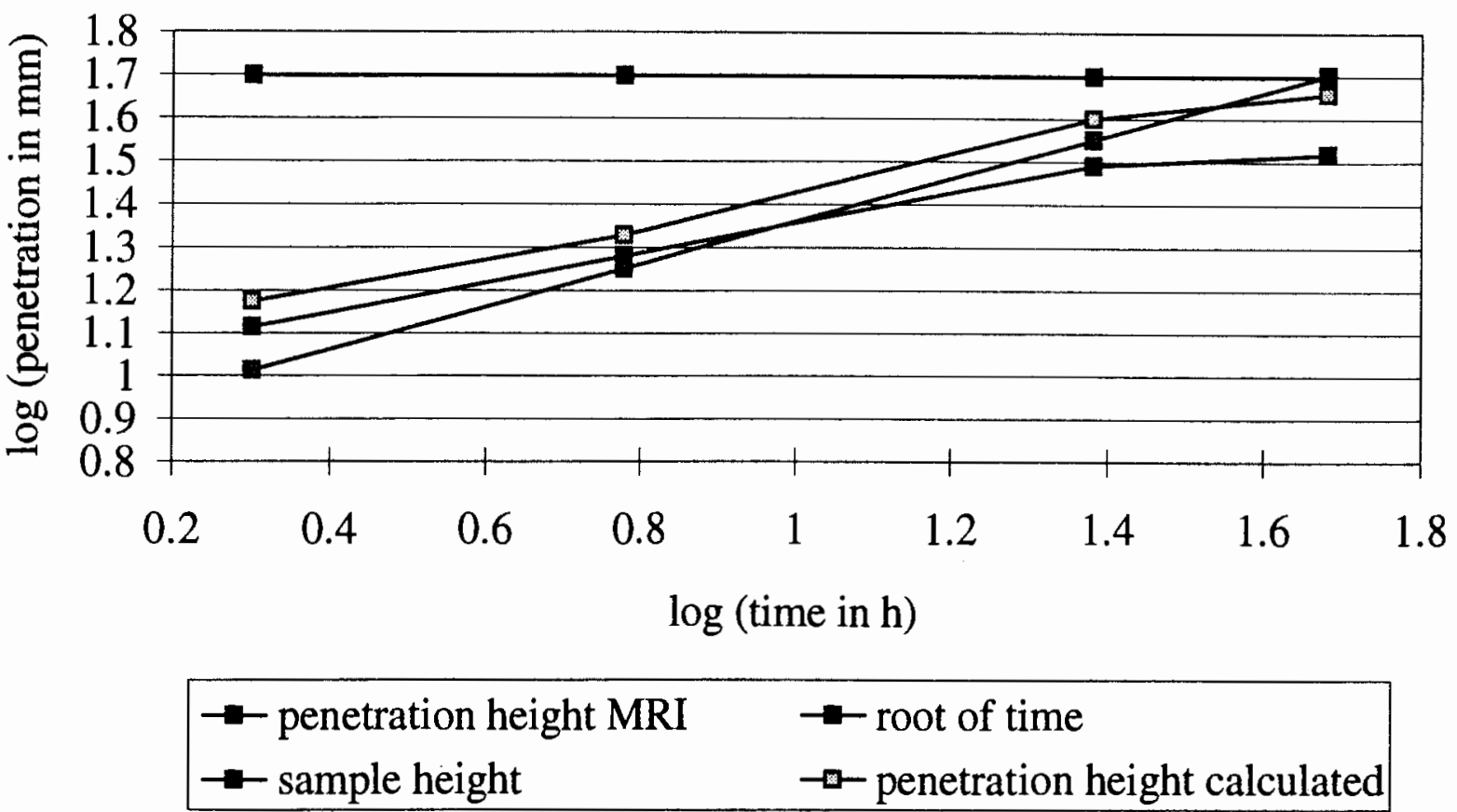

Fig, 12 Comparison of penetration height by MRI with calculated penetration height (suction test) of mix 3 prestored at $35 \%$ RH. 

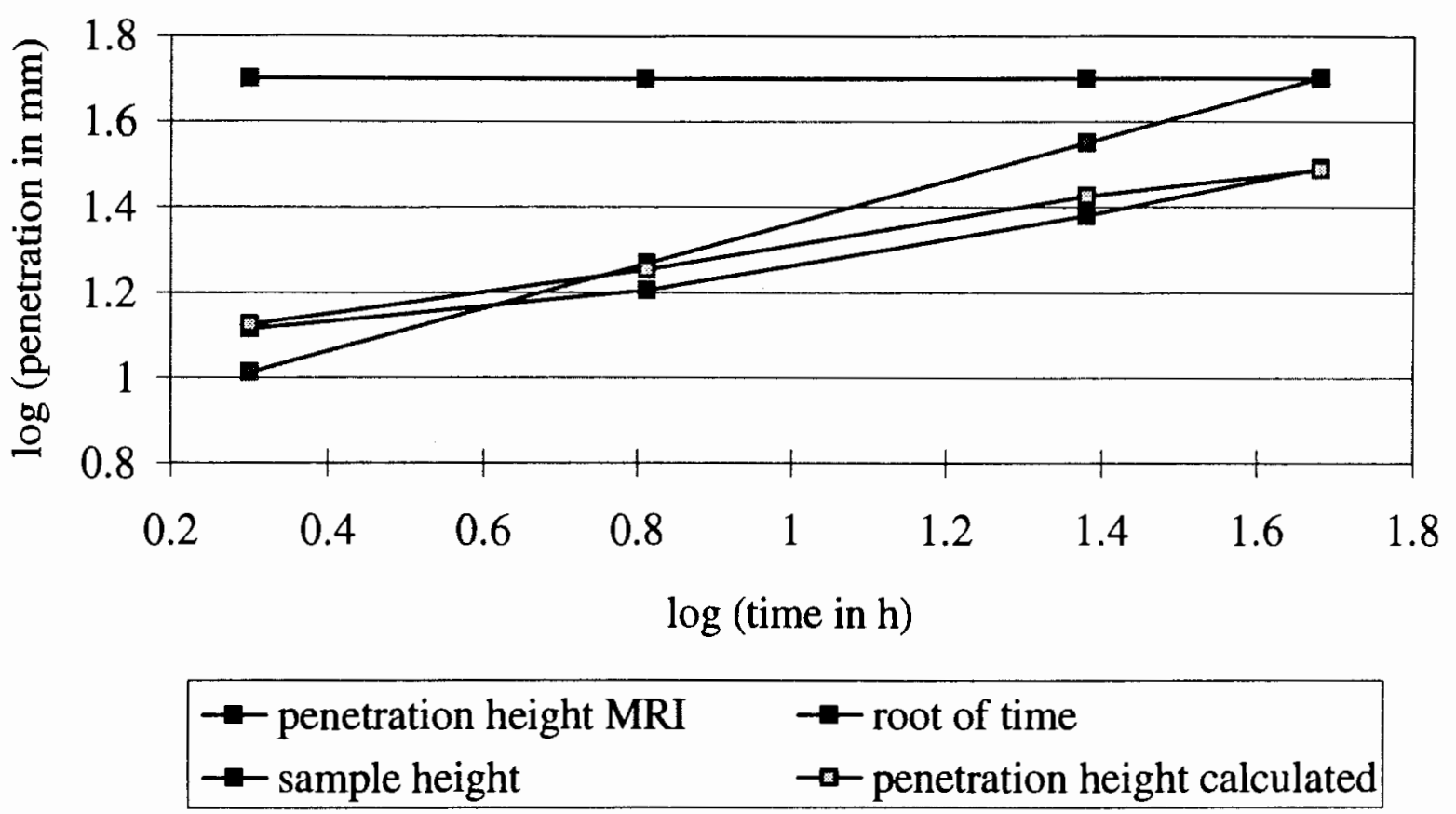

Fig. 13 Comparison of penetration height by MRl with calculated penetration height (suction test) of mix 4 prestored at $35 \% \mathrm{RH}$.

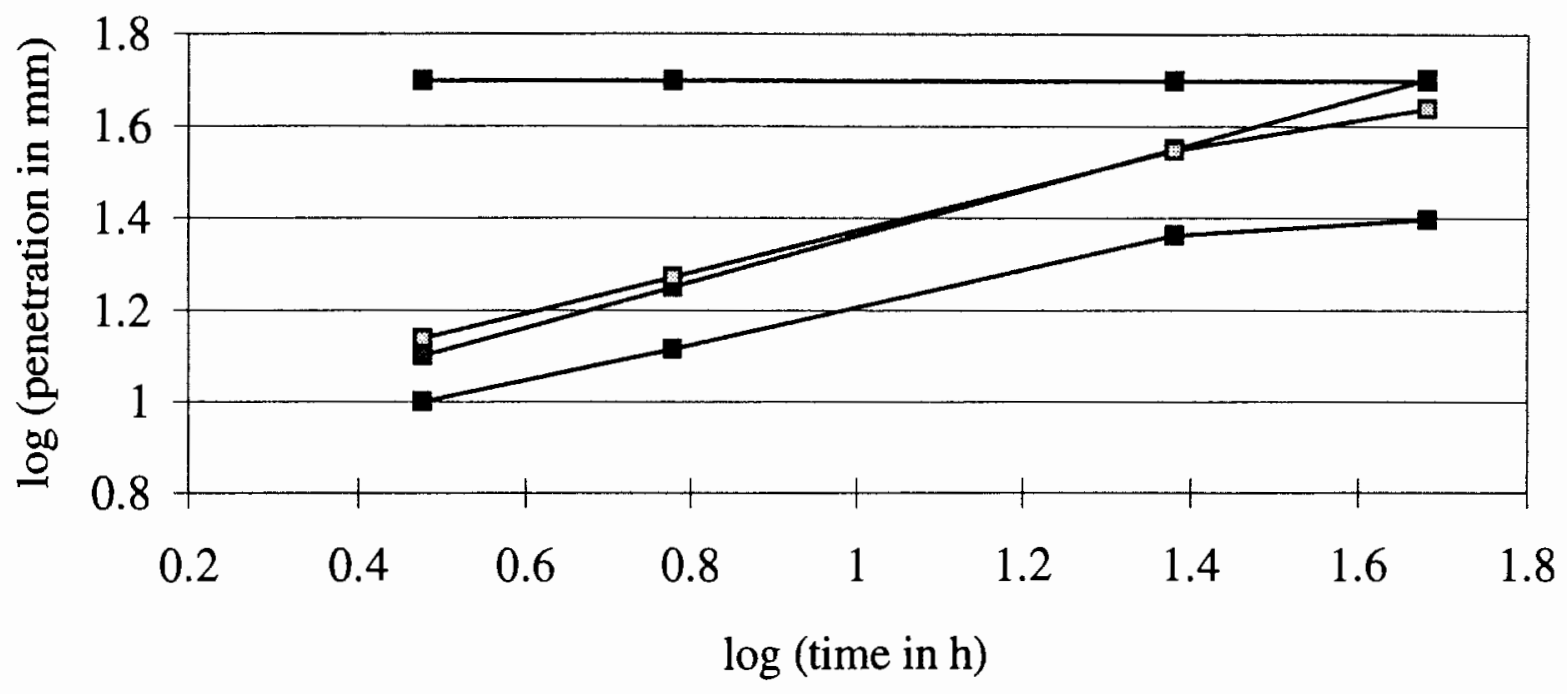

$\begin{array}{ll}\rightarrow-\text { penetration height MRI } & \rightarrow-\text { root of time } \\ \rightarrow-\text { sample height } & \rightarrow \text { - penetration height calculated }\end{array}$

Fig. 14 Comparison of penetration height by MRI with calculated penetration height (suction test) of mix 3 prestored at $90 \% \mathrm{RH}$.

than those of the samples stored at $35 \%$ RH. Fig. 16 shows a direct comparison.

\section{DISCUSSION OF RESULTS}

By using MRI, a front of upward moving water was observed during the suction test. The front heights were strongly dependent on prestorage humidities (Fig. 17). This is in contrast to mass measurement data, where the calculated heights were found to be independent of prestorage conditions. The only assumption for this calculation was that the incoming water fills empty pores completely to a certain height (front). The existence of a front was verified by means of MRI measurements. Taking a closer look at the problem, it is seen that with the two methods the front considered is not the same. With MRI the front of the 'new' incoming water (deuterated) is observed whereas with mass measurement method the front of total water is derived. These two fronts are not identical. This can be explained if it is assumed that 'new' water fills only connected empty pore space from below and that, simultaneously, 'old' water which was already present in the pores after prestoring moves forward and is replaced by 'new' water (Fig. 18). The force that pulls the water upwards comes from the meniscus built by the 'old' water. The 'new' water is 


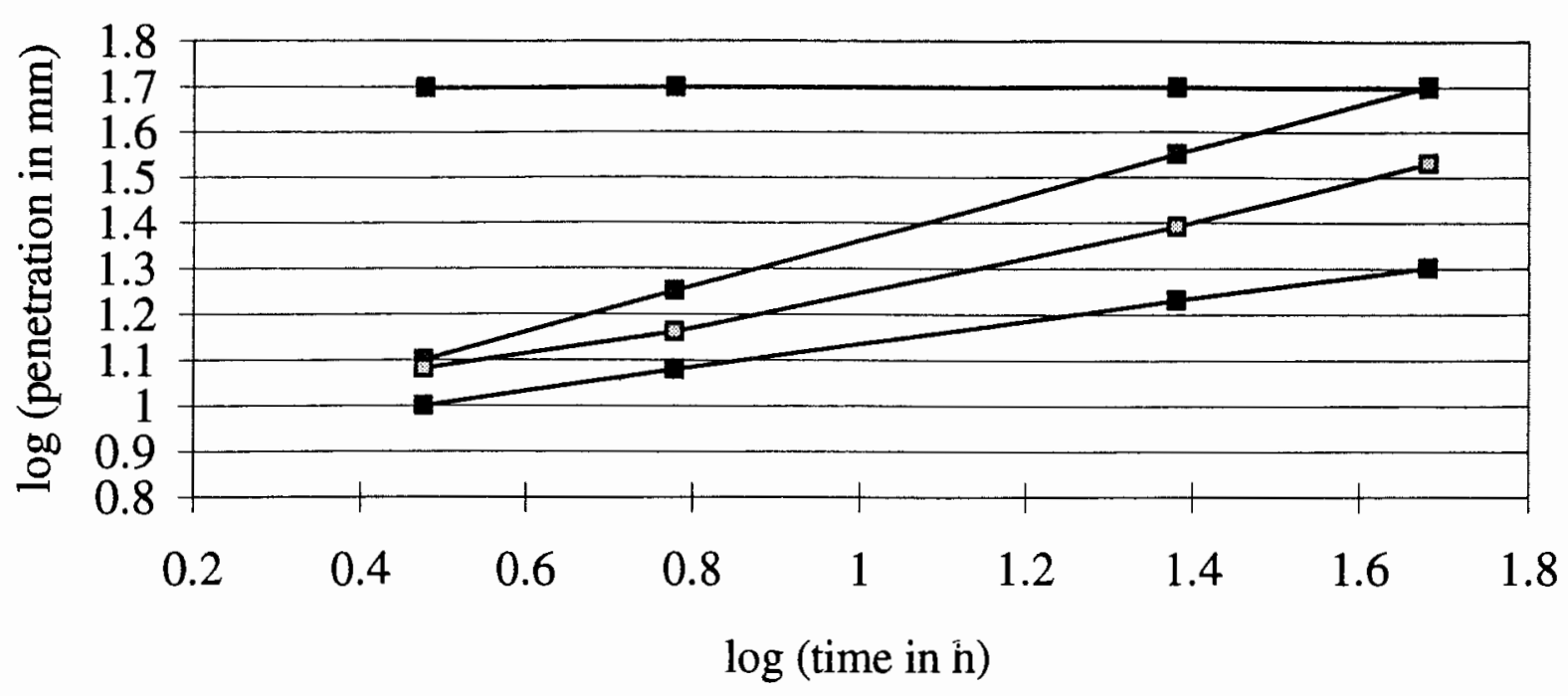

$\begin{array}{ll}\rightarrow \text { - penetration height MRI } & \rightarrow \text { - root of time } \\ \rightarrow \text { - sample height } & \rightarrow-\text { penetration height calculated }\end{array}$

Fig. 15 Comparison of penetration height by MRI with calculated penetration height (suction test) of mix 4 prestored at $90 \% \mathrm{RH}$.

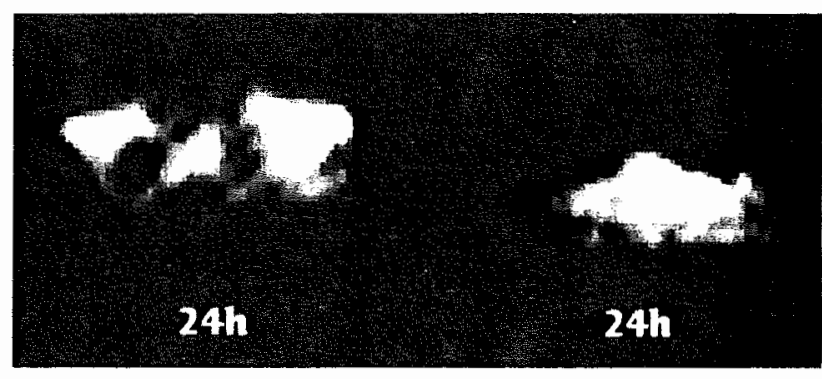

Fig. 16 Comparison between storage at $35 \% \mathrm{RH}$ (left) and $90 \% \mathrm{RH}$ (right) $(\operatorname{mix} 3)(\longmapsto-1010 \mathrm{~mm})$.

Storage at $35 \%$ R.H. Storage at $70 \%$ R.H.
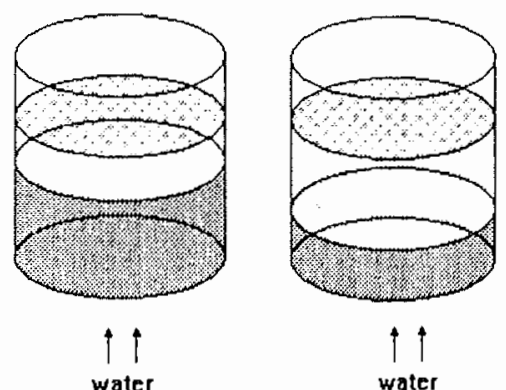

Fig. 17 Distribution of 'old' and 'new' water during suction as a function of the storage humidity.

drawn into the samples. Thus the 'new' water front depends on the prestorage humidities, i.e., the amount of water already present in the samples before the suction test starts. The following relation is found:

$$
h_{\text {new }}=(1-c) h_{\mathrm{tot}}
$$

where $c$ is the amount of replaced water, $h_{\text {new }}$ is the height of 'new' water (MRI), and $h_{\text {tot }}$ is the height of total water' (calc.). In a log-log plot the curves are therefore parallel.

Chloride ions responsible for local depassivation of the

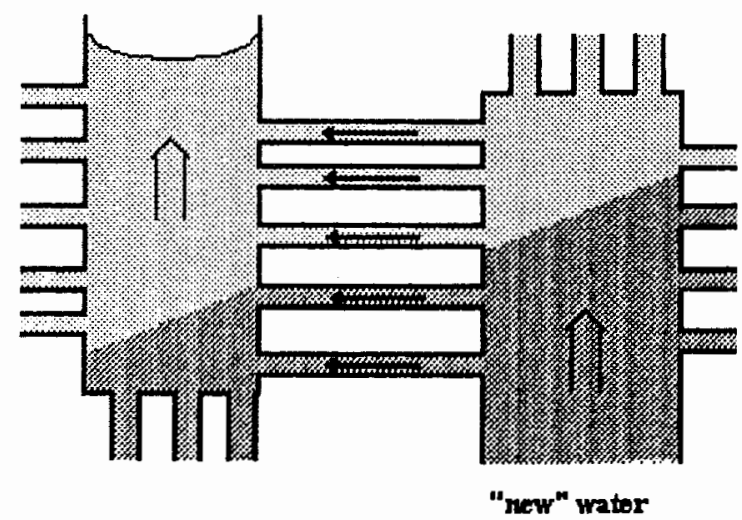

Fig. 18 Replacement of 'old' water by 'new' water.

reinforcing steel must therefore be considered to be transported in a similar way. If they are carried in with infloating water, the penetration depth for chlorides must be significantly lower than would have been expected. Therefore it is not necessary to resort to 'chemical' explanations for these observations [10]. No difference is expected between the calculated water front and the chloride front for samples totally dried at $105^{\circ} \mathrm{C}$ and this is indeed confirmed [11].

\section{CONCLUSIONS}

\section{Concerning water exchange}

The assumption of a front at the water uptake seems to be reasonable.

When not fully dried at $105^{\circ} \mathrm{C}$, the water front ingress calculated from mass measurement data is independent of the humidity content in concrete.

The measured deviations from root of time behaviour do not seem to be caused by an inhomogeneous humidity state but rather by the structure of the capillary and gel-pore system. 
Water exchange through covercrete differs significantly from water exchange through cut surfaces.

Water evaporation through covercrete shows two phases that are separated clearly and sharply:

First phase: Evaporation as from a free water surface (prop. $t^{0.77-0.89}$ ) therefore depending strongly on the surrounding humidity. Only the duration of this period depends on the concrete composition.

Second phase: Evaporation is almost independent of the surrounding humidity, but depends strongly on the concrete composition (prop. $t^{0.22-0.26}$ )

Ingress of 'new' water into the not completely dried out concrete is smaller than the visible ingress of the water front. Thus 'hanging back' of chlorides is caused not only by chemical (filtering) effects.

\section{Concerning further measurements}

Deuterium MRI proved to be an effective tool for investigating the spatial distribution of water transport in concrete.

The application of these techniques on a larger series and with different concrete types is desirable, as is optimizing the method.

\section{ACKNOWLEDGEMENTS}

The authors wish to express their gratitude to Dr. Th. Lüthi and A. Flisch (both at the EMPA, Dübendori, Switzerland), who carried out the $\mathrm{x}$-ray tomography measurements, and to Dr. J. Link and Dr. K. Schenker (both from Spectrospin AG, Fällanden, Switzerland), who made the MRI measurements possible.

\section{REFERENCES}

1. Quenard, D. and Sallee, H., 'A gamma-ray spectrometer for measurement of water diffusivity of cementitious materials', Mater. Res. Soc. Proc. 137 (1989).

2. Wittig, G. and Lingott, H., 'Untersuchung mit Mikrowellen zur Feuchtewanderung in Baustoff-proben, Bauphysik 14 (1992) 45-49.

3. Roth, K. et al., 'Calibration of time domain reflectometry for water measurement using a composite dielectric approach', Water Resources Res. 26 (1990) 2267-2273.

4. Yang, Q., 'Untersuchung des Betongefüges hinsichtlich der Beständigkeit unter besonderer Berücksichtigung des kapillaren Wassertransportes und der Chloridpenetration', Dissertation No. 8550, ETH Zürich, 1988.

5. Parrott, L. J., 'Water absorption in cover concrete', Mater. Struct. 25 (1992) 284-292.

6. Hall, C., 'Water sorptivity of mortars and concretes', Mag. Concr. Res. 41 (1989).

7. Kaufmann, J. and Studer W., 'Wasserhaushalt von Bauwerksbeton', EMPA-Report 139973, 1992.

8. Gummerson, R. et al., 'Unsaturated water within porous materials observed by NMR imaging, Nature 281 (1989) $56-57$.

9. Link, J. and Seelig, J., 'Comparison of deuterium NMR imaging methods and application to plants, J. magn. Reson. 89 (1990) 310-330.

10. Wittmann, F. H. and Lunk, P., 'Beeinfiussung des Feuchtigkeits- und Ionentransportes in Beton durch oberflächentechnologische Massnahmen', Strassenbauforschung des eidg. Dep. d. Inneren, Forschungsauftrag No. 81/88, 1991 .

11. Schiegg, Y., 'Transport von Wasser und Chloriden in Zemenststein bei verschiedenen Porositäten', Diplomarbeit Abt. Bauingenieurwesen ETH Zürich, 1990/1991.

\section{SUMMARY}

One-dimensional water transport in cores of different concrete types with a moulded surface at one end was investigated by the simple measurement of mass changes during suction and by evaporation tests. Non-destructive methods (magnetic resonance imaging (MRI) and $x$-ray tomography) were applied successfully to the localization of water distribution within the concrete during such

\section{RESUME}

Transport uni-dimensionnel de l'eau dans le béton d'enrobage - application de méthodes non destructives

Le transport de l'eau dans le béton d'enrobage est l'un des facteurs agissant le plus sur la durabiliteé des constructions en béton, en raison des effets notables qui en résultent sur la perméabilité au gaz, l'échange gazeux et le transport d'haloides et, par voie de conséquence, sur la corrosion de l'armature. Le transport de l'eau peut être quantifié simplement en procédant $\dot{a}$ des essais classiques d'absorption et d'évaporation. Une série d'essais de ce type ont été réalisés à l'EMPA.

$A$ cet effet, on a utilisé des carottes de petit diamètre $(50 \mathrm{~mm})$ et de différentes longueurs, munies à une extrémité d'une face de coffrage et provenant d'éléments de murs âgés tests. Before the suction test was carried out, all samples were stored for 18 months under constant climatic conditions $(35 \% \mathrm{RH}, 70 \% \mathrm{RH}$, or $90 \% \mathrm{RH})$ to avoid inhomogeneous humidity distributions. They were then sealed with aluminium tape (epoxy in the MRI measurement) on all faces except the moulded surface, thus guaranteeing one-dimensional flow.

de 4 à 5 ans, et qui ont été stockées dans des conditions climatiques constantes, jusqu'à I année et demie avant l'essai d'absorption. Le béton pouvait donc être considéré comme totalement hydraté et la réparitition de l'humidité dans les carottes était homogène au moment du démarrage des essais d'absorption. Quatre catégories de béton, différenciées par leur rapport eau/ciment $(0,5 ; 0,6)$ et la teneur en air ( $2 \%$ vol.; $5 \%$ vol.) ont été examinées. La teneur et la granulométrie des granulats (diam. max. des grains: $32 \mathrm{~mm}$ ) et, par conséquent, la quote-part volumétrique et la structure 'externe' de la pierre de ciment étaient identiques pour toutes les catégories de béton essayées.

Il est évident que les essais d'absorption et d'évaporation ne permettent de tirer que des conclusions à caractère global sur le transport de l'eau. Il n'en ressort aucune information sur la répartition géométrique de l'eau pendant 
les essais; pour cela, il est nécessaire d'avoir recours à des méthodes de mesures tomographiques non destructrices. Pour l'étude en cours, on a utilisé avec succès la radio-tomographie assistée par ordinateur et l'imagerie par résonance magnetique (IRM). En particulier, au moyen de l'IRM au deutérium, il a été possible, lors d'essais d'absorption, de rendre visibles des fronts ascendants; il semble donc raisonnable d'utiliser plus fréquemment cette méthode dans le cadre des recherches sur le transport de l'eau dans le béton d'enrobage.

Les résultats des essais ont permis de tirer quelques conclusions plus précises sur le transport de l'eau. On a pu constater, entre autres, que le béton d'enrobage se distinguait de manière évidente, également dans ce domaine, $d u$ béton interne et que les dérives observées quant à l'absorption de l'eau, par rapport à la 'loi de la racine carrée du temps', ne semblaient pas être provoquées par une répartition non homogène de l'humidité mais par la structure du système poreux capillaire. La comparaison de mesures IRM au deutérium avec des essais d'absorption classiques a permis de définir un modèle de pénétration d'eau dans un système poreux partiellement rempli. 